\title{
IMPLEMENTASI PNEUMATIK PADA MODEL PACKING
}

\author{
Natasya Vinalda ${ }^{1}$, Taopik Herdiansah ${ }^{2}$, Cahyani Wulan Hidayat ${ }^{3}$, \\ Adi Cahya Ramadhan ${ }^{4}$, B. S. Rahayu Purwanti ${ }^{5}$
}

1,2,3.4,5 Jurusan Teknik Elektro, Polteknik Negeri Jakarta, Jl prof.Dr.GA Siwabessy, Kampus Baru UI Depok 16425

e-mail :vinalda22@gmail.com

Diterima : 20 Agustus 2019. Disetujui : 17 September 2019. Diterbitkan: Oktober 2019

\begin{abstract}
This article discusses about practical modules at the Jakarta State of Polytechnic especially Industrial Electronics Study Program. Practical courses are equipped with simulations and modules as a means of learning. But some of the modules are not complete, especially pneumatic and Programmable Logic Controller (PLC). These problems cause students to lack insight into pneumatic and PLC applications. Pneumatic and PLC applications in the production can be made by module, especially packing. The creation of training module for the packing with pneumatic and PLC models is expected to improve competence and insight of students. Hardware and software are needed so that packing modeling is in accordance with how it works. Modeling is made into manual and automatic mode with PLC. PLC instruction activates solenoid valves through relay contacts. Relay coil contact is connected to the PLC output pin. Programming PLC in the form of a ladder diagram has been created on CX. Programmer 9.0. Normally closed relay is connected to one of the solenoid valve cables. Valves on solenoid valve deliver air pressure to both of double acting cylinders. The first of cylinder pushes object towards the conveyor and the second pushes object to the storage area.
\end{abstract}

Key word : module, packing, cylinder, solenoid valve, air pressure

\section{ABSTRAK}

Artikel ini membahas tentang modul praktik di Politeknik Negeri Jakarta khususnya Program Studi Elektronika Industri. Mata kuliah praktik dilengkapi simulasi dan modul sebagai sarana pembelajarannya. Namun sebagian modulnya belum lengkap khususnya pneumatik dan Programmable Logic Controller (PLC). Permasalahan tersebut menyebabkan mahasiswa kurang wawasan tentang pengaplikasian pneumatik dan PLC. Aplikasi pneumatik dan PLC pada produksi dapat dibuat modulnya, khususnya pengemasan barang. Pembuatan modul latih model pengemasan barang dengan pneumatik dan PLC diharapkan dapat meningkatkan kompetensi dan wawasan mahasiswa. Hardware dan software dibutuhkan agar pemodelan pengemasan sesuai dengan cara kerjanya. Pemodelan dibuat menjadi mode manual dan otomatis dengan PLC. Instruksi PLC mengaktifkan solenoid valve satu dan dua melalui kontak relay. Kontak coil relay terkoneksi dengan pin output PLC. Pemrograman PLC dalam bentuk ladder diagram telah dibuat di CX. Programmer 9.0. Normally closed relay terhubung dengan salah satu kabel solenoid valve. Katup pada solenoid valve menyalurkan tekanan udara ke silinder double acting satu dan dua. Gerakan maju/mundur silinder double acting satu mendorong barang menuju konveyor dan silinder dua mendorong benda ke tempat penyimpanan barang.

Kata Kunci : modul, packing, silinder, solenoid valve, tekanan udara 


\section{PENDAHULUAN}

Pendidikan di Politeknik Negeri Jakarta, Jurusan Teknik Elektro khususnya Program Studi Elektronika Industri, mata kuliah teori dan praktik terdapat di dalam kurikulumnya. Salah satu mata kuliah praktik yang diajarkan adalah Otomasi Industri. Fasilitas praktikum pada mata kuliah Otomasi Industri, memerlukan modul sebagai sarana pembelajarannya. Sebagian modulnya belum lengkap, khususnya pneumatik. Praktikum pneumatik dan Programming Logic Controller (PLC) yang diajarkan hanya sebatas simulasi. Hal tersebut dikarenakan modul praktik belum tersedia. Permasalahan tersebut menyebabkan kurangnya pemahaman mahasiswa tentang pemanfaatan pneumatik dan PLC. Aplikasi pneumatik dan PLC di industri untuk proses produksi, antara lain filling, sorting, milling, packing. Khususnya pengemasan memerlukan beberapa hardware dan software pendukung, dapat dimodelkan untuk sarana pembelajaran. Oleh karena itu, penulis tertarik membuat modul latih pneumatik dan PLC pada model packing. Harapannya modul tersebut bermanfaat sebagai sarana pembelajaran dan meningkatkan kompetensi mahasiswa. Selain itu sebagai bekal lulusan untuk berkompetensi dengan sesama teman dari PNJ atau PT lain saat mencari pekerjaan.

Selektor switch sebagai saklar posisi rangkaian secara manual atau otomatis dengan PLC. Modul input PLC menerima sinyal berupa tegangan dari output sensor dan push button [1]. Output dari PLC mengaktifkan solenoid valve melalui relay. Relay berfungsi mengamankan komponen elektronik dari kelebihan tegangan [2]. Kompresor berfungsi menyalurkan udara yang bertekanan pada sistem [3]. Solenoid valve beroperasi dengan arus listrik baik AC maupun DC. Solenoid valve mengatur saluran udara yang bertekanan ke aktuator pneumatic [4]. Silinder pneumatik berfungsi menggerakkan beban berat [5]. Pilot lamp menandakan indikator aktifnya sistem.

Permasalahan belum tersedianya modul praktik pneumatik dan PLC di PNJ diperlukan solusi. Modul Latih Pneumatik dan PLC pada Model Packing dirancangbangun untuk memperluas wawasan pengetahuan mahasiswa. Modul latih direalisasikan dengan memanfaatkan hardware dan software. Hardware yang dibutuhkan pada modul latih; PLC, relay, Air Service Unit (ASU), dua solenoid valve, dua silinder double acting, konveyor, motor DC, sensor reed switch, infrared proximity switch. Software CX Programmer $\quad 9.0$ dibutuhkan untuk pemrograman pada model packing. Implementasi pneumatik pada model packing dibuat secara manual atau otomatis dengan PLC. Output dari PLC mengaktifkan solenoid valve melalui kontak relay. Tekanan udara berasal dari kompresor, disaring dan diatur dengan ASU. Solenoid valve satu mengatur masuk/keluarnya tekanan udara pada silinder double acting satu (silinder 1) dan solenoid valve dua pada silinder double acting dua (silinder 2). Gerakan maju silinder 1 mendorong barang ke konveyor dan silinder 2 mendorong barang ke tempat penyimpanan. Indikator aktifnya modul berupa pilot lamp dan buzzer menandakan bahwa proses packing trouble.

\section{METODE PENELITIAN}

Metode penelitian model packing yaitu perancangan, realisasi, pengujian, pengambilan, dan analisis data.

\subsection{Spesifikasi Komponen Pneumatik}

a. Air Service Unit

ASU tipe AW2000-2 dengan tekanan operasi sebesar 0.05-0.085 MPa atau setara 50-850 bar. ASU berfungsi sebagai katup pemfilter udara. Udara yang masuk harus dipisahkan dari partikel-partikel. Partikel pada saluran udara menyebabkan gangguan pada elemen penggerak [3]. ASU juga berfungsi mengontrol tekanan udara yang masuk.

\section{b. Solenoid Valve}

Solenoid valve 5/2 tipe Airtac 4V210-08, beroperasi pada tekanan 0.15-0.8 MPa. Cara kerja: tegangan supply yang mengalir pada kumparan solenoid valve berubah menjadi medan magnet. Medan magnet pada kumparan 
berfungsi menggerakan plunger pada bagian dalam solenoid valve. Perpindahan posisi plunger menyebabkan lubang keluaran solenoid valve terbuka sehingga udara yang bertekanan keluar [6].

\section{c. Silinder Double Acting}

Silinder double acting tipe TMA-16X75 pada modul latih berjumlah 2 buah dengan tekanan operasi 0.1-1 MPa. Maksimal kapasitas beban silinder masing-masing $20 \mathrm{~kg}$. Silinder double acting memiliki dua port untuk instroke dan outstroke. Tekanan udara mendorong piston keluar dan kembali ke posisi awal. Silinder double acting [7] membutuhkan tekanan udara lebih besar dan katup pengontrol arah yang lebih kompleks dibandingkan dengan silinder single acting.

\subsection{Blok Diagram dan Flowchart}

Perancangan sesuai Blok Diagram (Gambar 1) dan realisasi keseluruhan model mengikuti diagram alir atau sesuai Flowchart (Gambar 2 a dan $b$ )

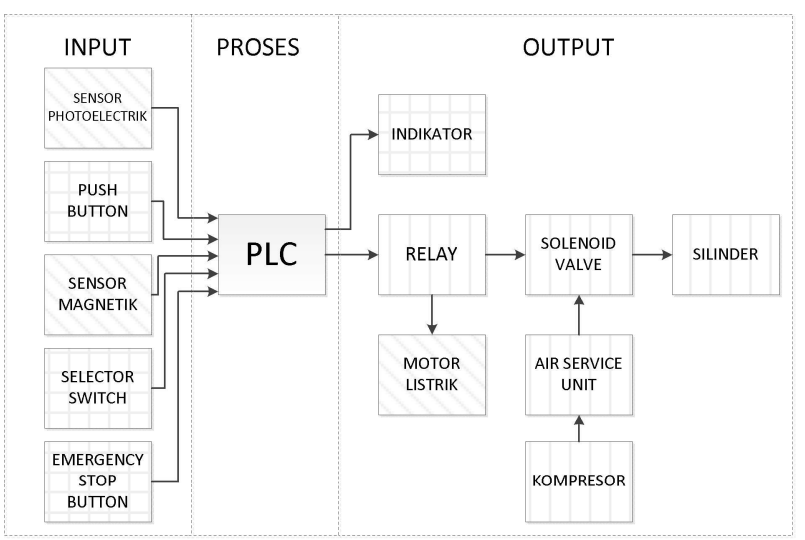

Gambar 1. Blok Diagram Keseluruhan Model

Keterangan:

Relay : relay dengan tipe MY4N sebagai kontak solenoid valve dari instruksi PLC.

Solenoid : dua buah solenoid valve jenis $5 / 2$ Valve difungsikan untuk mengatur saluran udara yang bertekanan ke silinder double acting.
Silinder : Silinder 1 mendorong barang ke konveyor dan silinder 2 mendorong barang ke tempat penyimpanan

ASU : sebagai pengatur tekanan udara dan pemfilter udara dari partikel.

Kompres : sebagai penghasil tekanan udara or pada modul latih.

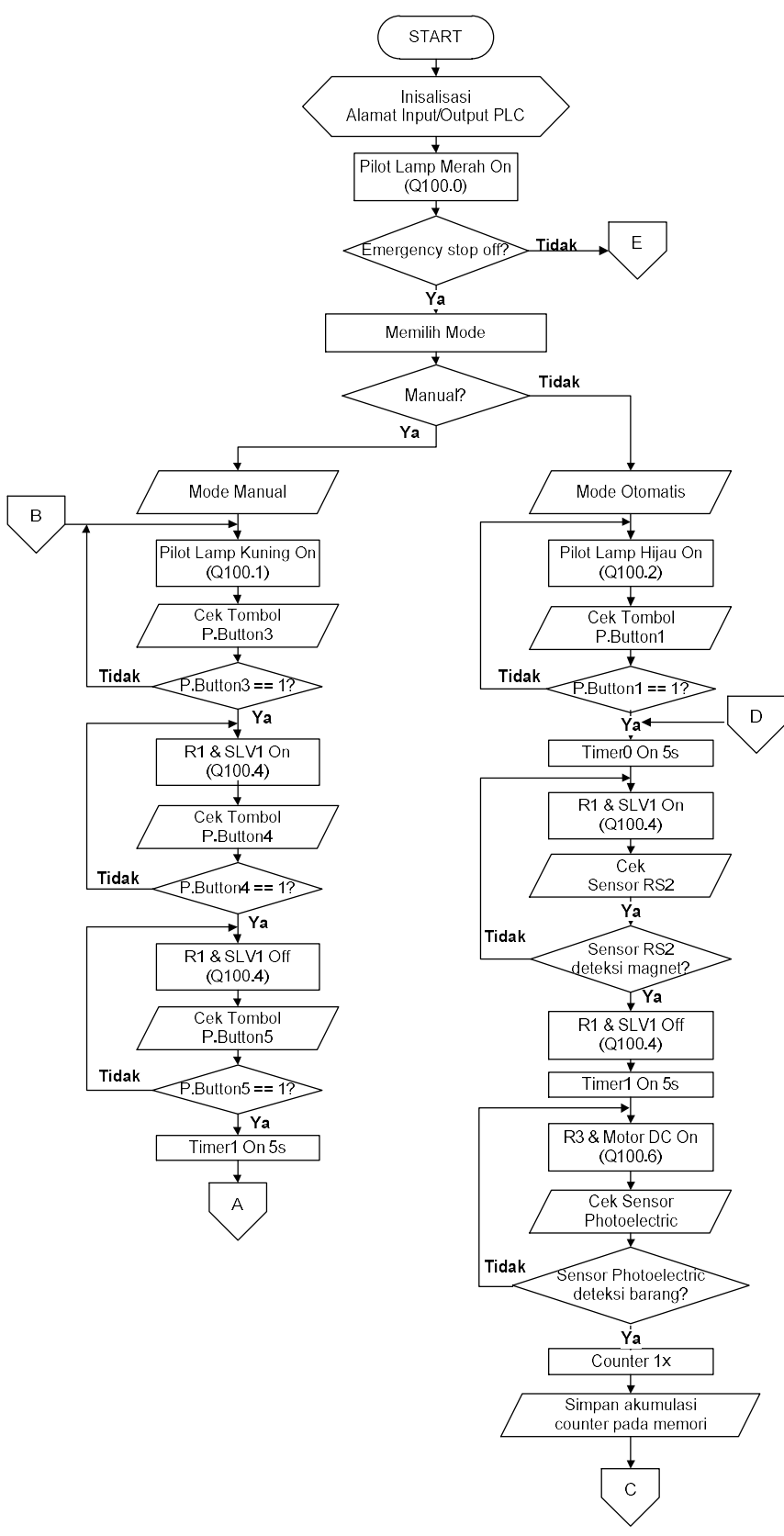

Gambar 2a Flowchart keseluruhan model 


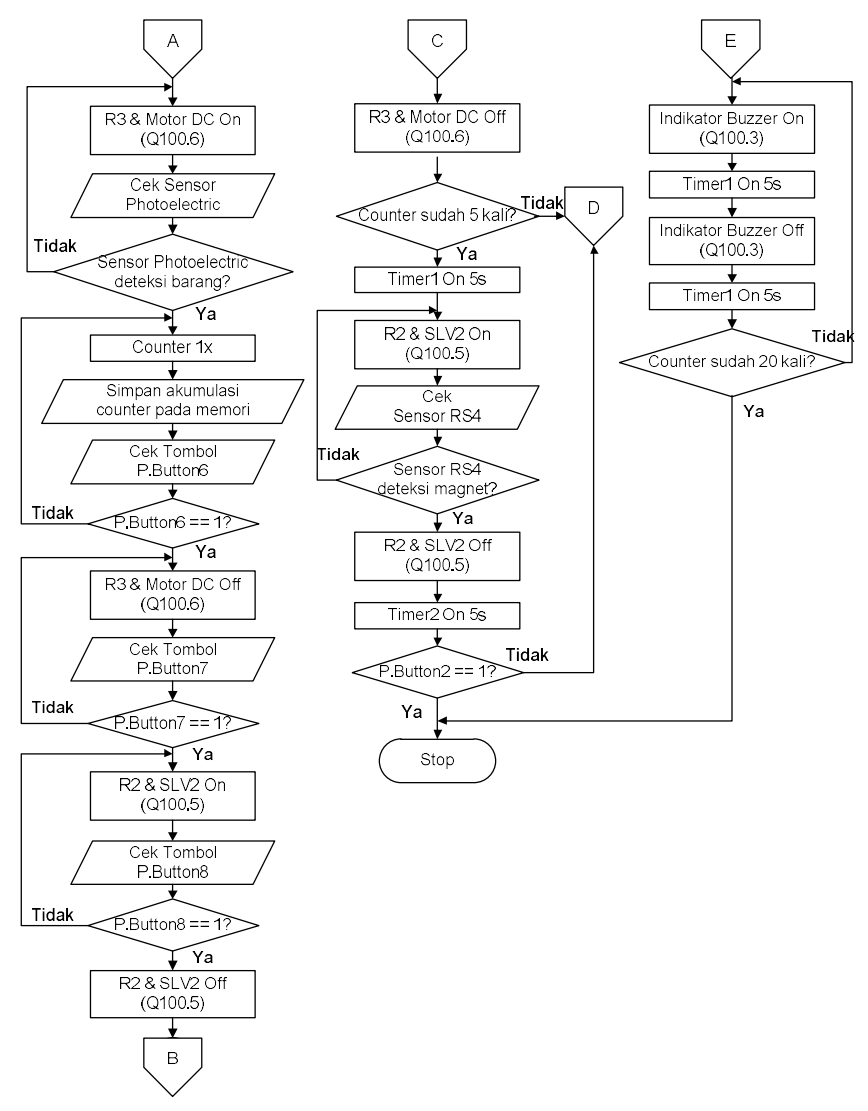

Gambar 2b. Flowchart Keseluruhan Model

\subsection{Pemasangan Komponen Pneumatik pada Modul Latih}

a. Pemasangan Solenoid Valve dan Silinder Double Acting dan Air Service Unit

Solenoid valve mengatur masuk/keluarnya udara yang bertekanan pada silinder. Pada gambar 3 (a) pin A solenoid valve dihubungkan dengan pin 1 silinder. Pin B solenoid valve dihubungkan dengan pin 2 silinder. Pembuatan standing board untuk memudahkan penempatan posisi silinder double acting.

Air service unit ditempatkan pada modul latih. Pemasangan standing board untuk memudahkan penempatan air service unit (Gambar 3 (b)).

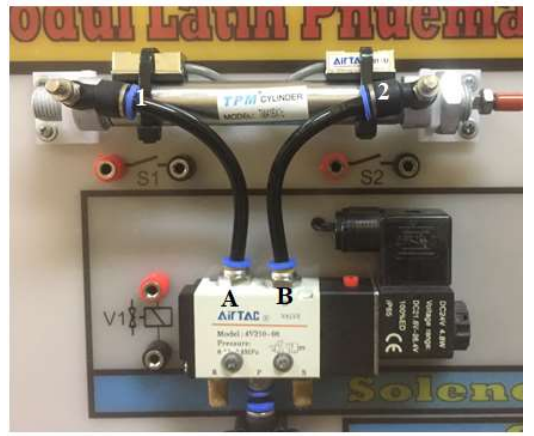

(a)

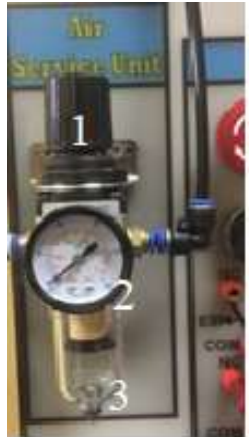

(b)
Gambar 3. Penempatan Solenoid Valve, Silinder Double Acting dan ASU

Keterangan Gambar 3 (b):

(1)Regulator (2) Pressure Gauge (3) Filter

b. Koneksi PLC, relay dan solenoid valve

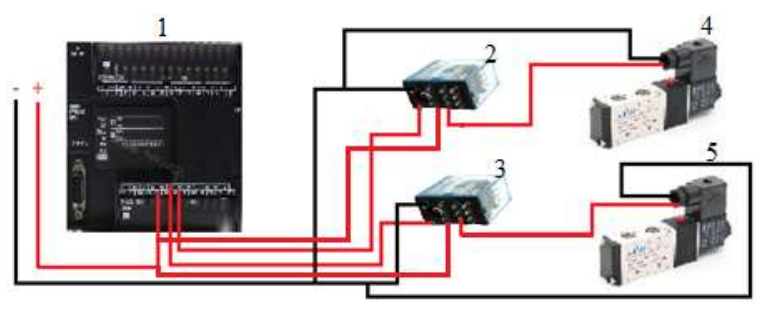

Gambar 4. Koneksi PLC, Relay dan Solenoid Valve

Keterangan Gambar 4:

(1) PLC (2 dan 3) Relay (4 dan 5) Solenoid Valve

Sinyal output PLC berupa tegangan di input ke coil relay untuk aktif. Pin output Q100.4 PLC dikoneksikan ke pin 14 relay 1 dan pin output Q100.5 PLC dikoneksikan ke pin 14 relay 2. Kontak Common pada relay terkoneksi dengan sumber tegangan +24 VDC. Normally Closed pada relay dihubungkan ke salah satu kabel solenoid valve. Sementara kabel solenoid valve lainnya dihubungkan dengan ground pada power supply (Gambar 4). 
c. Desain Modul Latih

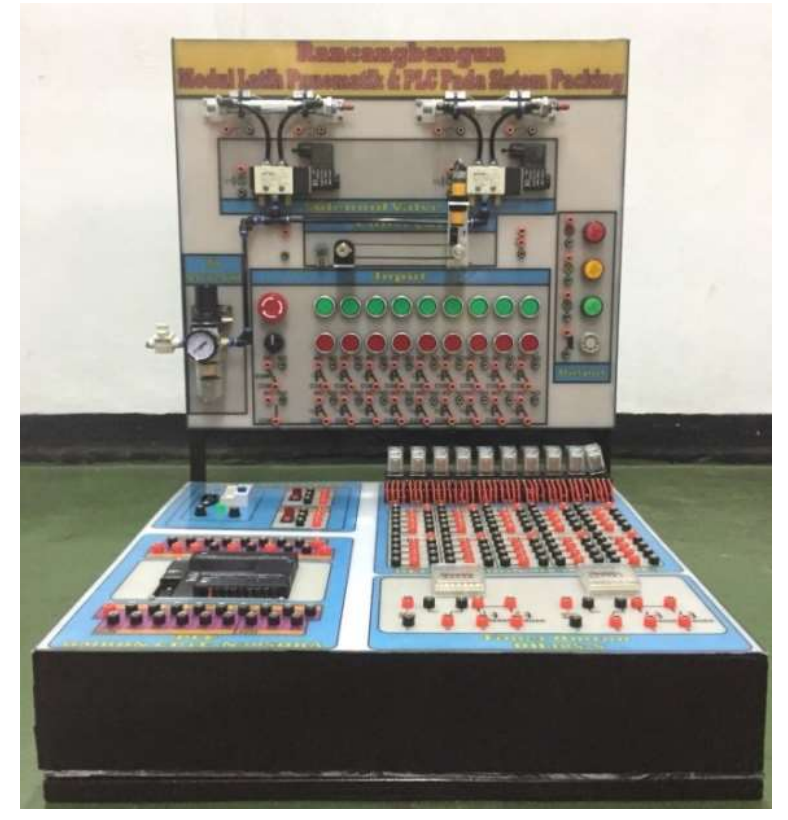

Gambar 5. Modul Latih Model Packing

Gambar 5 merupakan bentuk akhir dari modul latih (tampak depan). Modul latih memiliki dimensi ( $\mathrm{p}: 60 \times 1: 52 \times \mathrm{t}: 72) \mathrm{cm}$ berbahan Besi kotak dan akrilik 3-5 mm

\subsection{Cara kerja Modul}

a. Siapkan laptop, modul latih, kabel power, kabel USB printer, kabel banana, dan kompresor.

b. Pastikan kabel power modul latih dan kompresor terhubung ke sumber listrik.

c. Hubungkan kabel banana ke pin-pin actuator.

d. On-kan MCB dan tekan saklar 24V.

e. Hubungkan laptop dengan PLC dengan kabel USB printer.

f. Meng-upload program on/off relay yang sudah disiapkan.

g. Pasang selang dari kompresor ke modul latih.

h. Buka katup pada kompresor dan sesuaikan tekanan udara dengan mengatur regulator ASU.

i. Pilih posisi rangkaian dengan selektor switch ke mode manual atau otomatis.

j. Tekan push button (start) untuk mengoperasikan modul latih. k. Modul latih beroperasi.

1. Untuk menonaktifkan modul latih tekan tombol push button (stop).

m. Saat terjadi keadaan darurat saat pengoperasian modul latih, tekan emergency switch button dan buzzer akan bunyi.

\subsection{Uji Mekanik}

a. Pengujian gerak maju/mundur silinder double acting dengan tekanan udara dari kompresor.

b. Pengujian katup solenoid valve dengan catu daya dan kompresor.

\subsection{Uji Elektrik}

a. Pengukuran tegangan solenoid valve pada modul latih model packing. Besar tegangan yang sesuai (24 V) menunjukkan bahwa solenoid valve telah dapat diaktifkan atau dinonaktifkan. Alat ukur tegangan berupa voltmeter/ multimeter digital.

b. Pengujian relay sebagai kontak solenoid valve dengan alat ukur voltmeter/multimeter digital.

c. Pengukuran tekanan udara pada silinder double acting dengan alat ukur pressure gauge.

\subsection{Uji Software}

Pengujian program on/off relay untuk mengaktifkan/menonaktifkan solenoid valve.

\section{HASIL dan PEMBAHASAN}

Pengujian tekanan udara pada silinder 1 dan 2 diukur dengan pressure gauge. Indikator gauge menampilkan tekanan udara ASU, panjang selang terhadap tekanan udara pada silinder dan ASU umumnya sebanding. Oleh karena itu perlu dihitung selisihnya dengan cara pengukuran. Selisih tekanan udara tersebut diuji dengan panjang selang yang berbeda. 


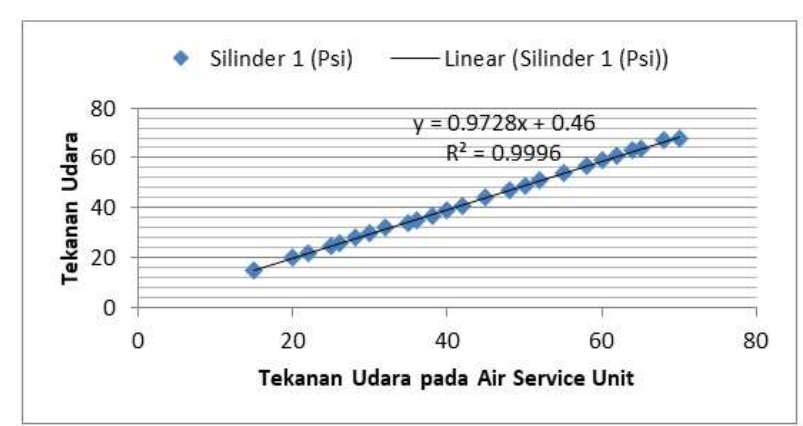

Gambar 6. Hasil Pengukuran Tekanan Udara

Silinder 1 (panjang selang 1 meter)

Trend grafik linier Gambar 6 menunjukan; tekanan udara minimum $=15 \mathrm{psi}$, maksimum $=$ 68 psi, rata-rata $=42,72$ psi. Hasil ukur pada ASU; tekanan udara minimum $=15$ psi, maksimum $=70$ psi, rata-rata $=43,44$ psi. Selisih tekanan udara rata-rata ASU-silinder $1=43,44$ $42,72=0,7 \mathrm{psi}=1,6 \%$. Hasil pengukuran tekanan udara pada silinder 1 sebanding dengan tekanan udara yang tertera pada ASU. Nilai regresi $\mathrm{R}^{2}=0,9996$ menunjukan bahwa $99,9 \%$ tekanan udara ASU sangat mempengaruhi tekanan udara pada silinder sedangkan $0,1 \%$ dipengaruhi oleh sebab lain dalam hal ini adalah panjang selang.

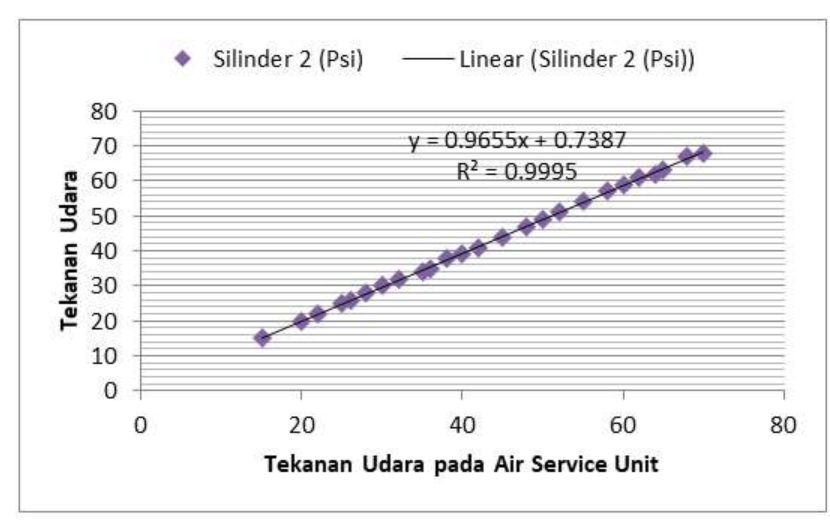

Gambar 7. Hasil Pengukuran Tekanan Udara Silinder 2 (panjang selang 1 meter)

Trend grafik linier Gambar 7 menunjukan; tekanan udara minimum $=15$ psi, maksimum $=$ 68 psi, rata-rata $=42,68$ psi. Hasil ukur pada ASU; tekanan udara minimum $=15$ psi, maksimum $=70$ psi, rata-rata $=43,44$ psi. Selisih tekanan udara rata-rata ASU-silinder $2=43,44$ -
$42,68=0,8 \mathrm{psi}=1,9 \%$. Hasil pengukuran tekanan udara pada silinder 2 sebanding dengan tekanan udara yang tertera pada ASU. Nilai regresi $\mathrm{R}^{2}=0,9995$ menunjukan bahwa $99,9 \%$ tekanan udara ASU sangat mempengaruhi tekanan udara pada silinder sedangkan $0,1 \%$ dipengaruhi oleh sebab lain dalam hal ini adalah panjang selang.

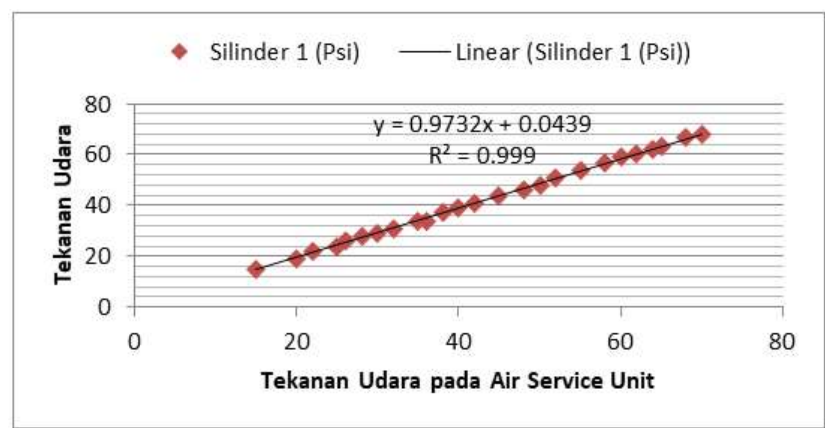

Gambar 8. Hasil Pengukuran Tekanan Udara Silinder 1 (panjang selang 2 meter)

Trend grafik linier Gambar 8 menunjukan; tekanan udara minimum $=15$ psi, maksimum $=$ 68 psi, rata-rata $=42,32$ psi. Hasil ukur pada ASU; tekanan udara minimum $=15$ psi, maksimum $=70$ psi, rata-rata $=43,44$ psi. Selisih tekanan udara rata-rata ASU-silinder $1=43,44$ $42,32=1,1 \mathrm{psi}=2,6 \%$. Hasil pengukuran tekanan udara pada silinder 1 sebanding dengan tekanan udara yang tertera pada ASU. Nilai regresi $\mathrm{R}^{2}=0,999$ menunjukan bahwa $99,9 \%$ tekanan udara ASU sangat mempengaruhi tekanan udara pada silinder sedangkan $0,1 \%$ dipengaruhi oleh sebab lain dalam hal ini adalah panjang selang.

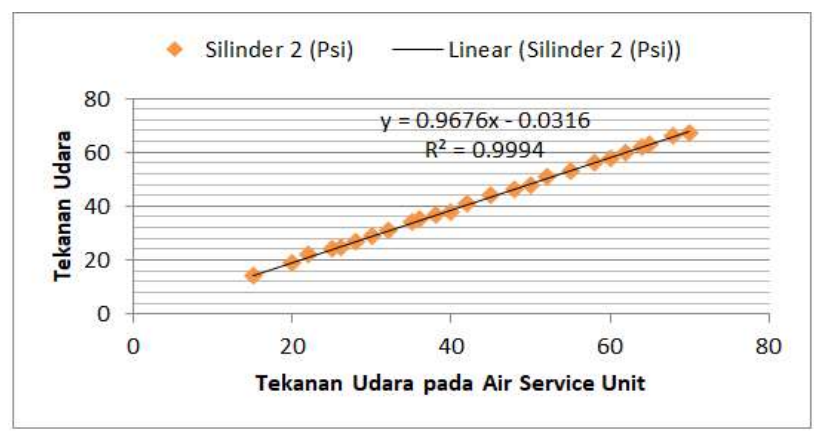

Gambar 9. Hasil Pengukuran Tekanan Udara Silinder 2 (panjang selang 2 meter) 
Trend grafik linier Gambar 9 menunjukan; tekanan udara minimum $=14$ psi, maksimum= 67 psi, rata-rata $=42$ psi. Hasil ukur pada ASU; tekanan udara minimum $=15$ psi, maksimum= 70 psi, rata-rata $=43,44$ psi. Selisih tekanan udara rata-rata ASU-silinder $2=43,44-42=1,4$ psi $=3,3 \%$. Hasil pengukuran tekanan udara pada silinder 2 sebanding dengan tekanan udara yang tertera pada ASU. Nilai regresi $\mathrm{R}^{2}=0,9994$ menunjukan bahwa 99,9\% tekanan udara ASU sangat mempengaruhi tekanan udara pada silinder sedangkan $0,1 \%$ dipengaruhi oleh sebab lain dalam hal ini adalah panjang selang.

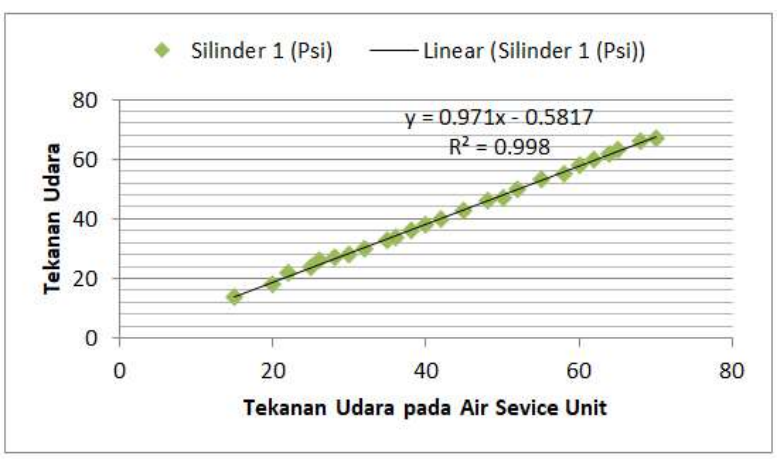

Gambar 10. Hasil Pengukuran Tekanan Udara

Silinder 1 (panjang selang 3 meter)

Trend grafik linier Gambar 10 menunjukan; tekanan udara minimum $=14$ psi, maksimum $=$ 67 psi, rata-rata $=41,6$ psi. Hasil ukur pada ASU; tekanan udara minimum $=15$ psi, maksimum $=70$ psi, rata-rata $=43,44$ psi. Selisih tekanan udara rata-rata ASU-silinder $1=43,44$ $41,6=1,8 \mathrm{psi}=4,3 \%$. Hasil pengukuran tekanan udara pada silinder 1 sebanding dengan tekanan udara yang tertera pada ASU. Nilai regresi $\mathrm{R}^{2}=$ 0,998 menunjukan bahwa 99,8\% tekanan udara ASU sangat mempengaruhi tekanan udara pada silinder sedangkan $0,2 \%$ dipengaruhi oleh sebab lain dalam hal ini adalah panjang selang.

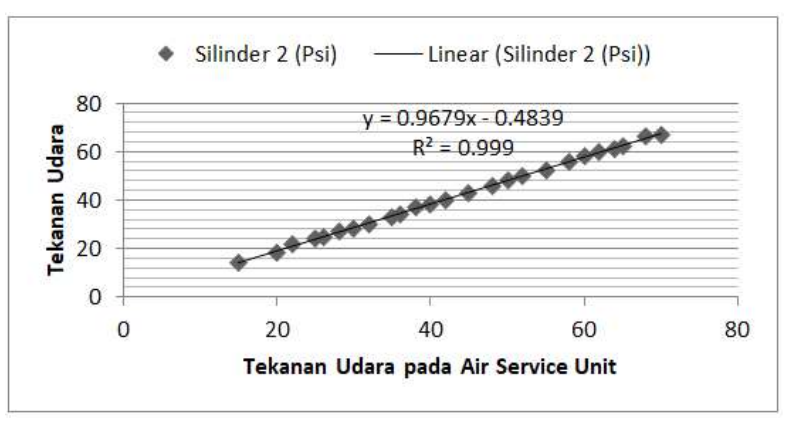

Gambar 11. Hasil Pengukuran Tekanan Udara Silinder 2 (panjang selang 3 meter)

Trend grafik linier Gambar 6 menunjukan; tekanan udara minimum $=14 \mathrm{psi}$, maksimum= 67 psi, rata-rata $=41,5$ psi. Hasil ukur pada ASU; tekanan udara minimum $=15$ psi, maksimum $=70$ psi, rata-rata $=43,44$ psi. Selisih tekanan udara rata-rata ASU-silinder 2 $=43,44$ $41,5=1,9 \mathrm{psi}=4,6 \%$. Hasil pengukuran tekanan udara pada silinder 2 sebanding dengan tekanan udara yang tertera pada ASU. Nilai regresi $\mathrm{R}^{2}=$ 0,999 menunjukan bahwa 99,9\% tekanan udara ASU sangat mempengaruhi tekanan udara pada silinder sedangkan $0,1 \%$ dipengaruhi oleh sebab lain dalam hal ini adalah panjang selang.

\section{KESIMPULAN}

Berdasarkan pengujian yang dilakukan dapat disimpulkan bahwa:

a. Hasil data pengukuran tekanan udara pada silinder 1 dan 2 sebanding dengan tekanan udara yang tertera pada Air Service Unit (ASU). Panjang selang tidak terlalu berpengaruh signifikan terhadap pengukuran tekanan udara pada silinder.

b. Relay difungsikan sebagai kontak solenoid valve pada kontrol maju/mundur silinder. Pengujian dari keseluruhan modul latih menunjukan model packing berfungsi dengan baik.

\section{Ucapan Terimakasih}

Terimakasih kami sampaikan kepada P3M PNJ atas diberikannya dana BTAM dan kepada Dra. B. S. Rahayu Purwanti selaku pembimbing yang telah membimbing hingga modul dan artikel ini selesai. 


\section{DAFTAR PUSTAKA}

[1.] Dewi, Tiar Kusuma, Priyo Sasmoko. 2014. "Aplikasi Programmable Logic Controller (PLC) Omron CP1E NA20 DRA Dalam Proses Pengaturan Sistem Kerja Mesin Pembuat Pelet Ikan". Jurnal GEMA TEKNOLOGI, vol. 17, no. 4, hh. 170-177.

[2.] Saleh, Muhamad, Munnik Haryanti. 2017. "Rancang Bangun Sistem Keamanan Rumah Menggunakan Relay”. Jurnal Teknologi Elektro, vol. 8, no. 3, hh. 181186. ISSN: 2086-9479.

[3.] Susanto, Riswan Eko Wahyu dan Syariif Al Ma'sum. 2015. "Rancang Bangun Mesin Pengolah Tahu Nigarin Semi Otomatis". Jurnal Teknik Mesin, vol. 4, no. 1, hh. 2638.

[4.] Latuconsina, Rina, L. H. Laisina, Ari Permana L. 2017. "Pemanfaatan Sensor PIR (Passive Infrared Receiver) dan Mikrokontroler Atmega 16 Untuk Efisiensi Pemakaian Air Wudhu". Jurnal Informatika:Jurnal Pengembangan IT (JPIT), vol. 2, no. 2, hh. 18-22. ISSN: 24775126.

[5.] Simarmata, Frans Gullit B, Riswan Dinzi. 2014. "Pemrograman Programmable Logic Controller (PLC) Pada Mesin Finger Joint". SINGUDA ENSIKOM, vol. 7, no. 2, hh. 6167.

[6.] Suharmanto, A., Akhmad Musafa. 2013. "Perancangan Sistem Pengisian Udara Ban Kendaraan Secara Otomatis Berbasis Mikrokontroler". Jurnal Arsitron, vol. 4, no. 1 , hh. 72-80

[7.] Subhan, M., Ari Satmoko. 2016. "Penentuan Dimensi Dan Spesifikasi Silinder Pneumatik Untuk Pergerakan Tote Iradiator Gamma Multiguna Batan". Jurnal Perangkat Nuklir, vol. 10, no. 2, hh. 50-61. ISSN: 1978-3515. 